\section{INFLUENCE OF STATIC MIXER ON THE FORMATION OF BIOGRANULES}

Suryati Sulaimana*, Azmi Aris', Abdul Syukor Abd. Razaka, Khalida Mudab, Aznah Nor Anuarc

aFaculty of Civil Engineering and Earth Resources, Universiti Malaysia Pahang, 26300 Kuantan, Pahang, Malaysia

bFaculty of Civil Engineering, Universiti Teknologi Malaysia, 81310 UTM Johor Bahru, Johor, Malaysia

cMalaysian-Japan International Institute of Technology, Universiti

Teknologi Malaysia, 54100 Kuala Lumpur, Malaysia
Article history

Received

5 May 2017

Received in revised form

25 July 2018

Accepted

1 August 2018

Published online

15 December 2018

*Corresponding author suryati@ump.edu.my

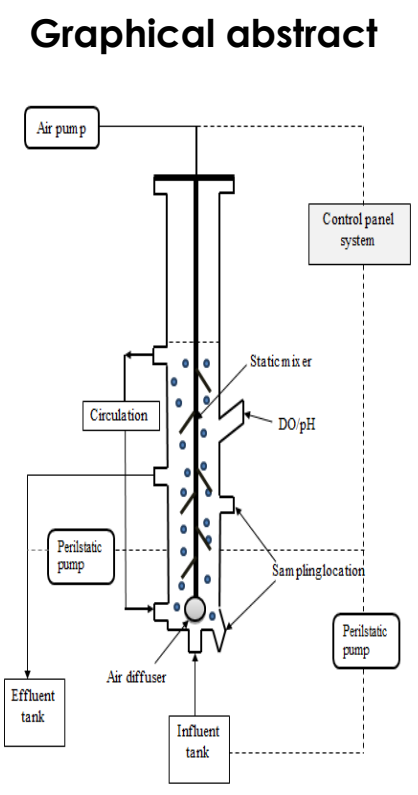

\begin{abstract}
Present study aimed at evaluating the formation of biogranules using sequencing batch reactors (SBRS) in treating textile wastewater under the influence of static mixer. Three sets of experiment were run with different superficial air velocity (SAV) of $0.5,1.4$ and $2.1 \mathrm{cms}^{-1}$, each set consisting of two SBR one with and one without static mixer. The developed biogranules in reactors with static mixer (R1M, R2M and R3M) showed good results after approximately 70 days. The biomass in the reactor reached mix liquor suspended solid (MLSS) of $5.75 \mathrm{gL}^{-1}$ with sludge volume index (SVI) of $107.4 \mathrm{mLg}^{-1}$ and settling velocity (SV) of $70.3 \mathrm{mh}^{-1}$ in R1M; MLSS of $7.18 \mathrm{gL}^{-1}$ with SVI of $29.5 \mathrm{mLg}^{-1}$ and SV of $80.4 \mathrm{mh}^{-1}$ for R2M and MLSS of $7.38 \mathrm{gL}^{-1}$ with SVI of $36.3 \mathrm{mLg}^{-1}$ and SV of 74.2 $\mathrm{mh}^{-1}$ for R3M. The use of static mixer has contributed to biogranules development with good settling properties.
\end{abstract}

Keywords: Biogranulation, static mixer, SBR, shear force, SAV

\begin{abstract}
Abstrak
Kajian ini bertujuan untuk menilai pembentukan biogranul di bawah pengaruh pengadun statik dan menggunakan reaktor jujukan bersiri (SBRs) dalam mengolah air sisa tekstil. Tiga set ujikaji dijalankan dengan halaju udara superfisial (SAV) 0.5, 1.4 dan $2.1 \mathrm{cms}^{-1}$, di mana setiap set terdiri daripada dua buah reaktor; satu mempunyai pengadun statik manakala satu lagi tiada. Biogranul yang dibentuk di dalam reaktor yang mempunyai pengadun statik (R1M, R2M dan R3M) menunjukkan prestasi yang baik selepas 70 hari. Biojisim telah menunjukkan prestasi campuran pepejal terampai likuor (MLSS) sebanyak $5.75 \mathrm{gL}^{-1}$, indeks isipadu enapcemar (SVI) $107.4 \mathrm{mLg}^{-1}$ dan halaju pengenapan (SV) $70.3 \mathrm{mh}^{-1}$ bagi R1M, MLSS $7.18 \mathrm{gL}^{-1}$, SVI $29.5 \mathrm{mLg}^{-1}$ dan SV 80.4 $\mathrm{mh}^{-1}$ bagi R2M dan MLSS $7.38 \mathrm{gL}^{-1}$, SVI $36.3 \mathrm{mLg}^{-1}$ dan SV $74.2 \mathrm{mh}^{-1}$ bagi R3M. Pengadun statik dilihat telah menyumbang kepada pembentukan biogranul yang mempunyai ciri-ciri pengenapan yang baik.
\end{abstract}

Kata kunci: Biogranul, pengadun statik, SBR, daya ricih, SAV

(C) 2019 Penerbit UTM Press. All rights reserved 


\subsection{INTRODUCTION}

Biogranulation technology has attracted an increased attention in recent years, due to its high effluent treatment quality, strong ability to withstand to organic loading, strong microbial structure and capability of high COD, nitrogen and phosphate removal [1]. As compared to the conventional activated sludge, biogranules have a regular, dense, strong structure and good settling properties [2, 3, 4] Most of the aerobic granular sludge has been obtained from SBR systems [5, 6, 7]. The operational parameters that influence the development of biogranules include hydrodynamic shear force, organic loading rate, substrate composition, settling time and hydraulic retention time $[8,9]$.

The hydrodynamic shear force resulted from aeration, which is generally measured as the superficial air velocity (SAV) has been reported to be one of the significant factors for biogranulation process. High hydrodynamic shear force could stimulate the surface hydrophobicity and the content of EPS to form more regular, strong structure and compact biogranules. In addition, high detachment force resulted from the high SAV can further shape the granules surface to become more smooth and dense [10]. According to previous studies, wide range of shear force has been successfully used to develop the aerobic granules $[11,12,13]$. Tay [14] reported that aerobic granules could only be formed at minimum SAV of $1.2 \mathrm{cms}^{-1}$ The significance of shear force in the granulation process was confirmed by Dulekgurgen [15]. It was reported that the formation and structure of granular sludge was influenced by the high shear force where aerobic granular sludge was observed at a SAV of $2.5 \mathrm{cms}^{-1}$ but was not developed at a low SAV 10.8 $\mathrm{cms}^{-1}$ ).

However, high SAV would lead to the requirement of high aeration energy in aerobic granular sludge system while lowering the hydrodynamic shear force using lower SAV is favourable due to economical reason. It will not be able to develop biogranules that possed that required characteristic. A static mixer was the element introduced in the reactor to enhance the hydrodynamic shear force even at low SAV. The main purpose of this work was to study the effect of static mixer combination with low SAV in the reactor on the properties of developed biogranules. Apparently, such study has never been reported before. The findings would provide a cheaper alternative for aerobic biogranulation system.

\subsection{METHODOLOGY}

\subsection{Wastewater Composition}

A synthetic textile wastewater having the composition described by Smolders [16] is shown in Table 1. Trace element solution used in this experiment was $1 \mathrm{mLL}^{-1}$. A total concentration of 50 $\mathrm{mg} \mathrm{L}^{-1}$ of Reactive Blue 4, Reactive Black 5 and Disperse Red 13 from Sigma-Aldrich, representing the common dyestuff used in textile industry were used as mixed dyes in this study. The COD of the synthetic wastewater was measured as $\pm 1500 \mathrm{mg} \mathrm{L}^{-1}$ resulted with OLR of $2.2 \mathrm{~kg}$ COD $\mathrm{m}^{-3} \mathrm{~d}^{-1}$. All rectors were inoculated with $750 \mathrm{~mL}$ (50\% of the total volume) of conventional activated sludge from a clarifier of the Municipal Wastewater Treatment plant, Taman Harmoni, Johor.

Table 1 Composition of synthetic wastewater

\begin{tabular}{|c|c|}
\hline Synthetic wastewater & Concentration $\left(\mathrm{gL}^{-1}\right)$ \\
\hline $\mathrm{NH}_{4} \mathrm{Cl}$ & 0.16 \\
\hline $\mathrm{KH}_{2} \mathrm{PO}_{4}$ & 1.42 \\
\hline $\mathrm{K}_{2} \mathrm{HPO}_{4}$ & 0.58 \\
\hline $\mathrm{CaCl}_{2} \cdot 2 \mathrm{H}_{2} \mathrm{O}$ & 0.18 \\
\hline $\mathrm{MgSO}_{4} .7 \mathrm{H}_{2} \mathrm{O}$ & 0.09 \\
\hline EDTA & 0.02 \\
\hline Trace element & Concentration $\left(\mathrm{gL}^{-1}\right)$ \\
\hline $\mathrm{H}_{3} \mathrm{BO}_{3}$ & 0.15 \\
\hline $\mathrm{FeCl}_{3} .4 \mathrm{H}_{2} \mathrm{O}$ & 1.5 \\
\hline $\mathrm{ZnCl}_{2}$ & 0.12 \\
\hline $\mathrm{MnCl}_{2} \cdot 4 \mathrm{H}_{2} \mathrm{O}$ & 0.12 \\
\hline $\mathrm{CuCl}_{2} .2 \mathrm{H}_{2} \mathrm{O}$ & 0.03 \\
\hline $\mathrm{NaMOO}_{4} \cdot 2 \mathrm{H}_{2} \mathrm{O}$ & 0.06 \\
\hline $\mathrm{CoCl}_{2} .6 \mathrm{H}_{2} \mathrm{O}$ & 0.15 \\
\hline $\mathrm{KI}$ & 0.03 \\
\hline
\end{tabular}

\subsection{Reactor Set Up}

A schematic diagram representation of the reactor set-up is given in Figure 1.

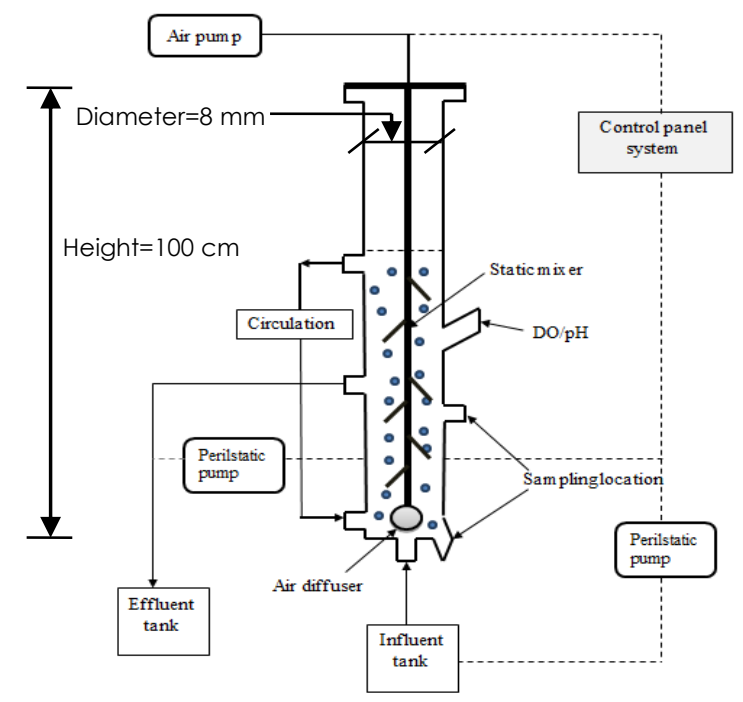

Figure 1 The schematic diagram of bioreactor system

The cylindrical columns used had a working volume of $1.5 \mathrm{~L}$ with internal diameter and total height of 8 and $100 \mathrm{~cm}$, respectively. A $100 \mathrm{~cm}$ long 
metal rod is placed at the centre of the reactor with attached 6 blades $(40 \mathrm{~mm})$, placed head down at $45^{\circ} \mathrm{C}$ and arranged alternately left and right was fixed for static mixing. In this study, 3 sets of experiment consist of two laboratory-scale SBR columns for each set were run. One of the reactors was equipped with static mixer (R1M, R2M and R3M) while the other one without static mixer (R1, R2 and R3) as control. Feeding, wastewater withdrawal and recirculation operations were controlled by peristaltic pumps.

\subsection{Experimental Procedures}

During the start-up period, $750 \mathrm{~mL}$ of seed sludge and $750 \mathrm{~mL}$ of synthetic textile wastewater was added into the reactor system resulting in an initial MLSS concentration of $2 \mathrm{gL}^{-1}$ in the reactor. Raw sludge taken from sewage treatment plant was used as seed sludge for the inoculation of the reactors. The seed sludge appeared fluffy having loosed structure with brown color. The reactors were operated with intermittent phase in a 8 hours cycle time which consisted of filling (5 min), anaerobic (220 min), aerobic (240 min), settling (5 min), idle (5 min) and decant (5 min). Fine air bubbles were introduced by a diffuser placed at the bottom of reactor at SAVs of $0.5 \mathrm{cms}^{-1}$ for R1 and R1M, $1.4 \mathrm{cms}^{-1}$ for R2 and R2M and $2.1 \mathrm{cms}^{-1}$ for R3 and R3M. Aeration took place only during the react phase of the sequencing batch reactor cycle. Recirculation of the wastewater was maintained during anaerobic phase to achieve a homogeneous distribution of substrate as well as uniform distribution of suspended biomass along the reactor depth. The treated wastewater was removed after the settling phase was completed from the effluent port located at $15 \mathrm{~cm}$ from the bottom of the reactor which gives the volumetric exchange ratio as $50 \%$. The details of the reactor operational configuration are shown in Table 2. The OLR of $2 \mathrm{kgm}^{-}$ ${ }^{3} d^{-1}$ was applied in all reactors throughout this development stage. The experiments were carried for a total of 70 days for each run.

Table 2 Reactors details operational configuration

\begin{tabular}{lllll}
\hline Reactor & $\begin{array}{l}\text { SAV } \\
\text { (cms }\end{array}$ & $\begin{array}{l}\text { HRT } \\
\text { (hours) }\end{array}$ & $\begin{array}{l}\text { OLR } \\
\text { (kgm- }\end{array}$ & Static Mixer \\
\hline R1 & 0.5 & 8 & 2.0 & Without \\
R1M & 0.5 & 8 & 2.0 & With \\
R2 & 1.4 & 8 & 2.0 & Without \\
R2M & 1.4 & 8 & 2.0 & With \\
R3 & 2.1 & 8 & 2.0 & Without \\
R3M & 2.1 & 8 & 2.0 & With \\
\hline
\end{tabular}

\subsection{Analytical Methods}

Mixed liquor suspended solid (MLSS) was measured by collecting the sample from reactors. The dissolved oxygen (DO) and $\mathrm{pH}$ were continuously monitored and recorded by a pH/DO meter (Orion 4-Star Benchtop $\mathrm{pH} / \mathrm{DO}$ Meter). The granules developed in the SBR column were periodically collected and analysed for their physical characteristics including SVI, SV, granules diameter and strength. The SVI procedure was carried out according to the method suggested by de Kreuk [17]. The settling velocity was determined using a measuring cylinder. A granule was placed at the top and the time taken for the granule to settle through a certain distance in the cylinder was recorded [18]. The granular strength was expressed as integrity coefficient (IC) and was determined following the procedures described by Ghangrekar [19]. Sludge morphology and size distribution of the developed granules were characterized using a stereo microscope equipped with digital image analyser (I-Solution Premium). The effect of static mixer on biogranules characteristics was analysed using Paired-samples T-test. A value of $p \leq 0.05$ was defined as significant. The statistical analysis was conducted using the Statistical Package for Social Sciences (SPSS) 21.

\subsection{Image Analysis}

The complete granulation process from seeding sludge to mature granules was investigated and documented by using an image analyser system (iSolution Premium) which was connected to a microscope (Leica 2100). The observed samples were taken from the reactors during the aeration phase while granules were mixed well in the reactors.

\subsection{RESULTS AND DISCUSSION}

\subsection{Biomass Profile and Settling Ability of Developed Granules}

Figure 2 demonstrated the biomass concentration during the whole development stage of granules. Most of the solids were washed-out from the reactors during the early stage of the development. This condition has caused a rapid decreased in SVI values and increased of settling velocities which was related to the decrease in MLSS content of the reactors. The reactors were start up with initial range MLSS of 1.97 to $2.44 \mathrm{gL}^{-1}$. A recovery in biomass concentration was observed after day 15 where MLSS concentration in all reactors kept increasing. The reason seems to be that the microorganisms in the bioreactors started to adapt themselves to the wastewater. The biomass growth indicated by MLSS increased in the 3 sets of reactors under the same operation strategy. A faster increase in MLSS was detected in RIM as compare to RI reflecting that static mixer helps to enhance the aeration and in turn enhances the development of granules. There was an indication of formation of aerobic granules in RIM as expected at this time. However, the biomass present in R1 during this period was filamentous with 
fluffy and loose structure. The concentrations were observed to increase continuously until the end of experimental run.

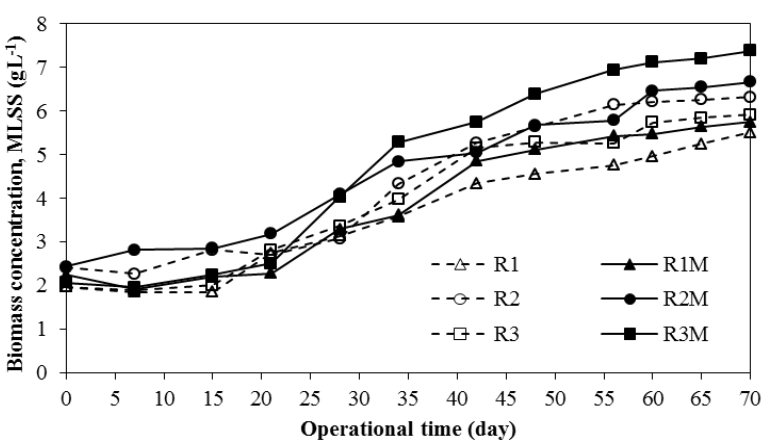

Figure 2 The variations of biomass concentration of the reactors

A similar trend occurred in set 2 of the experiment, R2 and R2M. Smaller granules were observed earlier in R2M on day 15, most probably attributable to having a static mixer in the reactor. An increasing trend of MLSS were observed onwards and reached $6.32 \mathrm{gL}^{-1}$ of MLSS for R2 and $6.67 \mathrm{gL}^{-1}$ of MLSS for R2M on day 70. Similar phenomenon was also observed during the experimental run in R3 and R3M. In comparison to R3, granules appeared in R3M sooner for about 34 days, the MLSS was increased to $5.36 \mathrm{gL}$ 1. The reason for such different results is related to the addition of static mixer in R3M. After 70 days of operation, MLSS were 5.51, 5.75, 6.32, 7.18, 5.92 and $7.38 \mathrm{gL}^{-1}$ in R1, R1M, R2, R2M, R3 and R3M, respectively.

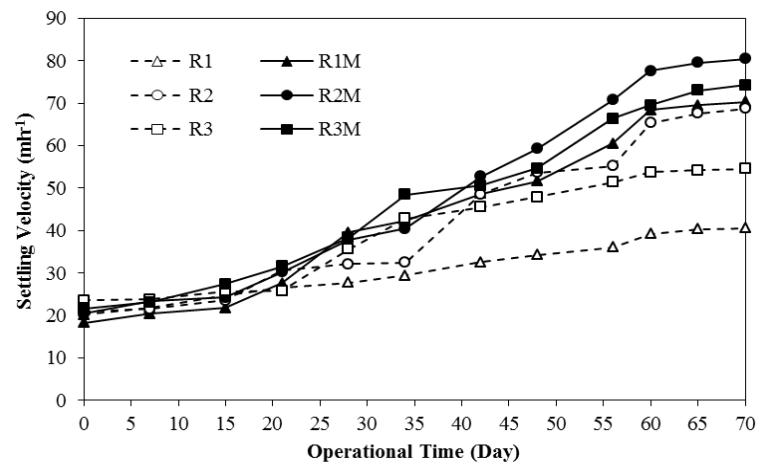

Figure 3 Profile of settling velocity of granules during development stage

As shown in Figure 3, a significant difference on settling velocity between RI and RIM can only be seen on day 28 where granule settling velocity was found to be higher in RIM (39.5 $\mathrm{mh}^{-1}$ ) as compared to $\mathrm{R} 1\left(27.7 \mathrm{mh}^{-1}\right)$. The appearance of granules in set 2 was witnessed by the increase of settling velocity in R2M. It can be observed that settling velocities of R2 and R2M were respectively $32.1 \mathrm{mh}^{-1}$ and $37.8 \mathrm{mh}^{-1}$ on day 28 , and these values continued to increase till day 70 (R2-68.7 $\mathrm{mh}^{-1}$ and R2M-80.4 $\mathrm{mh}^{-1}$ ). Settling velocity of R3 was only $32.1 \mathrm{mh}^{-1}$ on day 28 . Due to the SAV of $2.1 \mathrm{cms}^{-1}$, the value started to increase and reached $54.4 \mathrm{mh}^{-1}$ at the end of the experiment. In the opposition, settling velocities of R3M were much stable and reached $74.2 \mathrm{mh}^{-1}$ due to the higher aeration rate combined with static mixer.

With the continuous operation of reactor, the settling characteristic of the sludge were promoted and the SVI values were decreased to $133.6 \mathrm{~mL} \mathrm{~g}^{-1}$ and $107.4 \mathrm{~mL} \mathrm{~g}^{-1}$ for $\mathrm{R} 1$ and $\mathrm{R} 1 \mathrm{M}$ at the end of the operational day (Figure 4). The SVI of granules in R2 (37.8 $\mathrm{mL} \mathrm{g}^{-1}$ ) on day 70 was obviously lower than in R2M $\left(29.5 \mathrm{~mL} \mathrm{~g}^{-1}\right)$. It is clearly shown that the settling ability of granules from R2M improved more than those of R2 and other reactors, confirming that the static mixer had an influence on the granules development. Moreover, it was also found that the $S V I$ in the reactor with static mixer R3M, was higher than that of in R3. The results indicate that the sludge settling properties were improved significantly with the increase of SAV and addition of static mixers. The steady-state biomass concentrations in the reactors with static mixer (R1M, R2M and R3M) were high as compared to other reactors and reached the value of $5.75,7.18$ and $7.38 \mathrm{gL}^{-1}$. The matured granules were first formed in these three reactors compared to other reactors (R1, R2 and R3).

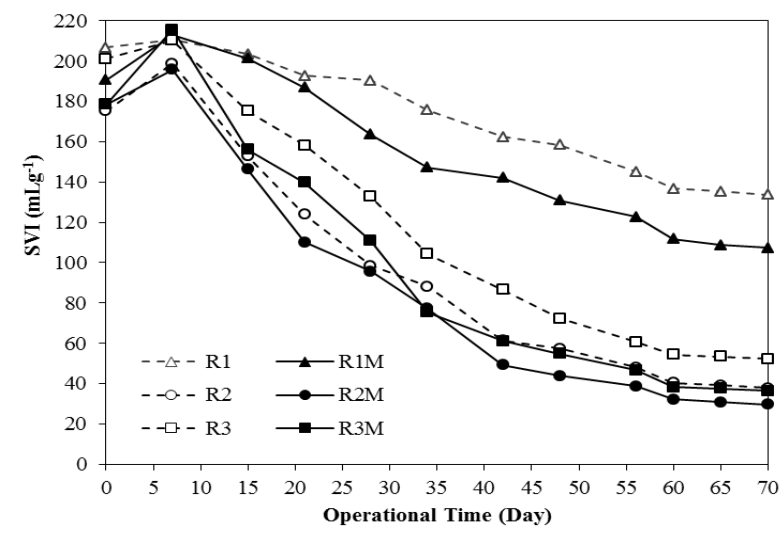

Figure 4 Profile of SVI granules during development stage

On the other hand, the biomass concentrations in R1, R2 and R3 were low and stabilised at 5.51, 6.32 and $5.92 \mathrm{gL}^{-1}$. The settling ability of the developed biogranules was improved with the increase of biomass concentration. The settling velocity and SVI were increased in the rectors with static mixer. These results are higher than the values 30-35 $\mathrm{mh}^{-1}$ reported by Tay [20] and are in agreement with the results obtained by Muda [21] with settling velocity value of $80 \mathrm{mh}^{-1}$ in cultivating aerobic granules in synthetic textile wastewater. The decrease in the SVI values was an indication of granules formation. It also shows 
that R2 and R2M took about 42 days to obtain SVI under $60 \mathrm{~mL} / \mathrm{g}$, where R2M value $\left(49.2 \mathrm{~mL} \mathrm{~g}^{-1}\right)$ was much lower than R2 (57.4 $\left.\mathrm{mL} \mathrm{g}^{-1}\right)$. While R3 and R3M took longer time (60 days) to decrease the SVI value below 60. Until the end of the experimental phase, SVI value for RI and RIM decreased only to $133.6 \mathrm{~mL}$ $\mathrm{g}^{-1}$ and $107.4 \mathrm{~mL} \mathrm{~g}^{-1}$, respectively. The results show that the SVI values were affected when a static mixer was used to supply aeration intensity. Adav [22] found that that more than 40 days are needed to decrease the SVI to below $60 \mathrm{~mL} \mathrm{~g}^{-1}$. Sludge generally has good settling characteristics if the SVI values range from 80 to 120 . Comparing the six results from all reactors, it is obvious that the biogranules formed in R2M presented very good settling properties than those in other reactors.

According to T-test paired samples as shown in Table 3, a positive correlation were found between reactor with and without static mixers. It was observed that mean score of MLSS in R1M ( $\mathrm{m}=3.71)$ is higher than $\mathrm{Rl}(\mathrm{m}=3.98)$ at $\mathrm{p}=0.01$. The same pattern was found between R2 and R2M where the mean score for R2 was 4.45 and R2M was 4.70 and this result is significant at the $p=0.04$. Strong evidence of influence of static mixer was also found in R3M when the significant difference, $p=0.001$. The results demonstrate that the stage of the biogranulation process as well as biomass concentration in the reactor influenced by the addition of static mixers. The statistical analysis also revealed that there was a significant difference in SV between all reactors $(\mathrm{p}<0.05)$. The mean score for $\mathrm{R} 1$ is 31.1 while $\mathrm{R} 1 \mathrm{M}$ is 44.91 and at significant level $p=0.003$. Meanwhile, in set 2, there were also a significant difference in R2 $(m=43.33)$ and $R 2 M(m=49.74)$ at $p=0.002$. The same pattern was observed in batch 3 where mean score of R3M ( $m=48.23)$ is slightly higher than R3 $(m=40.38)$ with $p=0.004$. The result also shows that the mean score of SVI for RI is 170.92 and RIM is 152.13 at significant level $p=0.001$. In the case of R2 and R2M, the SVI of granules in R2 $\left(37.8 \mathrm{~mL} \mathrm{~g}^{-1}\right)$ on day 70 was obviously lower than in R2M $\left(29.5 \mathrm{~mL} \mathrm{~g}^{-1}\right)$ confirming that the static mixer had an influence on the granules development. A higher hydrodynamic shear force which comes from the interaction between SAV and static mixer would lead to more attrition, high detachment resulted in a stronger granules and good settling ability. At the same time the high shear force promoted more secretion of EPS to bridging cells within the biogranules together which promoted the settleability of biogranules. Moreover, it was also found that the SVI in set 3, the reactor with static mixer R3M, was higher than that of in R3. The statistical analysis also showed that the mean score of R3M ( $m=95.87)$ is slightly greater than R3 $(m=113.43)$ at $p=0.001$. These results confirm that the granulation process was more rapid when the reactor was equipped with static mixer

\subsection{Granular Strength}

The integrity coefficient (IC) representing the granules strength under different hydrodynamic shear force is depicted in Figure 5. According to definition, the lower the integrity coefficient stands for the higher strength of the sample [23]. It was demonstrated that under the same hydraulic retention time, the granules strength in reactor was inclined with the increase of SAV and the addition of static mixer. The IC values at initial stage were $75.7 \%$ for R1, R1M (73.1\%), R2 (71.6\%), R2M (72.1\%), R3 (76.5\%), R3M (72\%), respectively. At early development stage of granules, the microbes within the granules were loosely together and may contain more cavities which made the granules less dense as evident by the low settling velocity values.

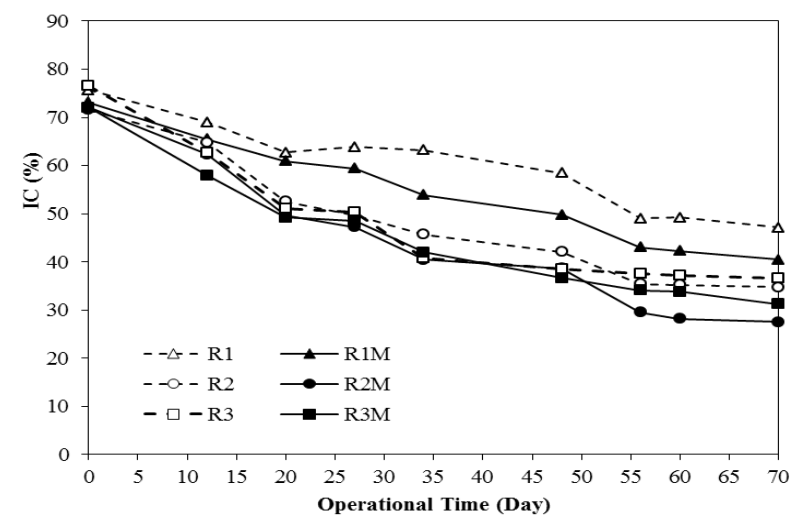

Figure 5 Profile of granule strength along the operational time

On day 70 , the IC was decreased to $47.1 \%, 40.5 \%$, $34.7 \%, 27.5 \%, 36.6 \%$ and $31.2 \%$ for R1, R1M, R2, R2M, R3 and R3M, respectively; indicating that high SAV and static mixer were beneficial to develop matured granules and improves the strength. Compared with granules in all reactors, the granules in R2M had better physical strength with higher IC of $27.5 \%$ at the end of the experiment. These values are lower than the values that were reported by Liu [24] which were in the range of $77-99 \%$. The decreasing IC value indicates the increase in strength of the bond that holds microorganisms together within the granules. There was a statistically significance in mean of IC $(p<0.05)$ between two reactor for all sets of experiment as clearly shown in Table 3 . It was observed that the granules strength in $\mathrm{R} 2(\mathrm{~m}=54.27)$ is affected by the addition of static mixer compared to R1 $(m=59.80)$ with significant different $p=0.001$. A positive correlation was also found between R2 and $\mathrm{R} 2 \mathrm{M}$; and R3 and R3M. The mean score for R2 is 47.96 while $R 2 M$ is 43.94 at $p=0.001$, whereas $R 3(m=47.92)$ and $R 3 M(m=45.04)$ at $p=0.003$ showing the increase strength of granules. The IC values appeared to decreased in reactor with static mixer, which shows that the strength of granules increase further when 
adding static mixers to the reactors as opposed to reactors without static mixers. With higher shear force, long starvation time and the helps of static mixers in R1M, R2M and R3M, the aerobic granules developed with high integrity and thereby high physical strength suggesting that granules had a stronger microstructure compared to others. Under the applied of hydrodynamic shear force, microbes may produce more EPS within the granules and the cavities within the granules may be filled. The EPS could also contribute greatly to strengthen the structural integrity of the aerobic granules and cause it to become denser and stronger as shown by their high value of settling velocity and low IC value at the termination of experiment.

Table 3 Paired samples T-test statistical analysis

\begin{tabular}{|c|c|c|c|c|c|c|c|c|}
\hline \multirow{2}{*}{ Reactor } & \multicolumn{2}{|c|}{ MLSS (gL-1) } & \multicolumn{2}{|c|}{$S V\left(m^{-1}\right)$} & \multicolumn{2}{|c|}{ SVI $\left(\mathrm{mLg}^{-1)}\right.$} & \multicolumn{2}{|c|}{ IC (\%) } \\
\hline & Mean & $\mathrm{P}$ & Mean & $\mathrm{P}$ & Mean & $P$ & Mean & $P$ \\
\hline R1 & 3.71 & \multirow[b]{2}{*}{0.01} & 31.1 & \multirow[b]{2}{*}{0.003} & 170.92 & \multirow[b]{2}{*}{0.001} & 59.80 & \multirow[b]{2}{*}{0.001} \\
\hline RIM & 3.98 & & 44.91 & & 152.13 & & 54.27 & \\
\hline R2 & 4.45 & \multirow[b]{2}{*}{0.04} & 43.33 & \multirow[b]{2}{*}{0.002} & 93.43 & \multirow[b]{2}{*}{0.001} & 47.96 & \multirow[b]{2}{*}{0.001} \\
\hline R2M & 4.70 & & 49.74 & & 85.65 & & 43.94 & \\
\hline R3 & 4.10 & \multirow{2}{*}{0.001} & 40.38 & \multirow{2}{*}{0.004} & 113.43 & \multirow{2}{*}{0.001} & 47.92 & \multirow{2}{*}{0.003} \\
\hline R3M & 4.91 & & 48.23 & & 95.87 & & 45.04 & \\
\hline
\end{tabular}

\subsection{Granules Morphology}

The seed sludge was an irregular and loose structure morphologically. During the first 7 days of sludge acclimatization, most of the biomass in all reactors was washed-out due to very low settling velocity and leaving behind the biomass with better settleability. Only traces filamentous bacteria predominated in all reactors. After sludge acclimatization, the filamentous bacteria slowly disappeared and a vast number of small granules started to aggregate. In set 1, granules were first observed in R1M after 15 days of reactor running. Filamentous bacteria were still present in the reactors but their concentration decreased progressively. In contrast, an observation on Rl did not show much difference and indicates that the biomass that cultivated in the reactor had a fluffy, irregular and loose-structured morphology similar to those of the original seed sludge. Until day 45, observation showed no sign of granules formation, neither was there any possibility of granule formation but rather there were fluffy flocs in R1, while suspended flocs gradually appeared in the reactor RIM. These observations are likely to be related to the fact that a certain value of shear force is needed for good granulation process and high shear force seems to favour the formation of more regular and compact granules. In fact, Beun [25] also reported that lower superficial air velocity did not favour the formation of stable aerobic granules in the same type of reactors.

Upon mature granulation on day 70 as demonstrated in Figure 6 , the reactor reached steady state where no flocs were found and the fluffy and loosely packed granules of $0.2 \mathrm{~mm}$ of average diameter were grew up in R1M which was operated at a SAV of $0.5 \mathrm{cms}^{-1}$ and with the addition of static mixer. In R1, only flocs were observed and no granules were formed during the whole experimental period. In set 2, granulation in R2M occurred at faster rate than in $\mathrm{R} 2$ demonstrating that combination of high SAV and static mixer had enhanced the development of granules.

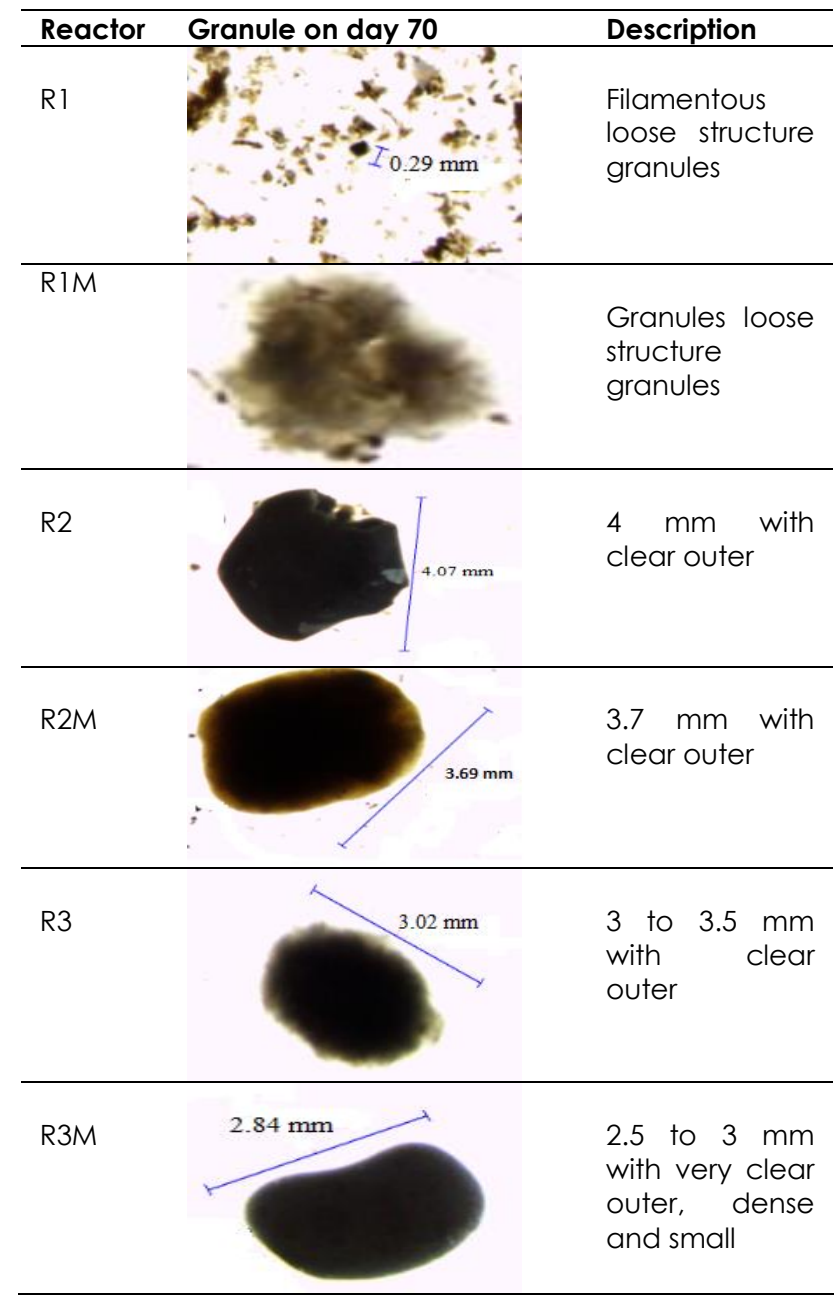

Figure 6 Granular sludge sizes on day 70 
At the end of experiment the average size of granules in R2 was $4 \mathrm{~mm}$ slightly larger to those in R2M $(3.7 \mathrm{~mm})$. On the other hand, in set 3, R3 and R3M also showed the same pattern of granules development. The difference was that the aerobic granules formed in R3M showed a very clear boundary compared to granules in R3. In addition, the average size was around 2.5 to $3 \mathrm{~mm}$ in R3M and 3 to $3.5 \mathrm{~mm}$ in $\mathrm{R} 3$, which indicated that different granules were appeared under the same SAV but the addition of static mixer.

Comparison among the SBRs suggests faster biomass growth in reactors equipped with static mixer which facilitates the granules formation and growth. Upon the completion of aerobic granulation, the sludge settleability improved greatly. In these six reactors, the time needed for the granules development was different. The sequence of appearance of smooth granules in SBRs was R2M (30 days), R3M (45 days), R2 and R3 (70 days) while a small aggregates covered by filamentous organisms was formed in R1M. Only filamentous granules were observed in R1 until the end of the experiment. The results obtained from this stage are in agreement with previous researches that proved a sufficiently high shear force is needed for aerobic granule formation [26]. Experimental results also showed the utilization of static mixer in the reactor system strongly influenced the hydrodynamics and shear force on the development of granules.

\subsection{CONCLUSION}

The result demonstrated that high SAV and the addition of static mixer influenced the granulation process. The reactor with SAV of $1.4 \mathrm{cms}^{-1}$ and static mixer showed the highest strength of bonding in terms of IC value (27.5\%), corresponding to the lowest value of SVI $\left(29.5 \mathrm{mLg}^{-1}\right)$ and highest value settling velocity $\left(80.4 \mathrm{mh}^{-1}\right)$. In addition, statistical analysis showed a significant difference $(p<0.05)$ between the reactors with and without static mixers indicating the efficiency of static mixer to enhance the system in developing aerobic granules.

\section{Acknowledgement}

The authors would like to thank Universiti Malaysia Pahang (UMP) and Universiti Teknologi Malaysia (UTM) for providing necessary facilities to conduct this experiment.

\section{References}

[1] Ma, J., Quan, X. and Li, H. 2013. Application of High OLRfed Aerobic Granules for the Treatment of Low-strength Wastewater: Performance, Granule Morphology and Microbial Community. Journal of Environmental Sciences. 25(8): 1549-1556.
[2] Wang, X., Zhang, H., Yang, F., Wang, Y. and Gao, M. 2008. Bioresource Technology Long-term Storage and Subsequent Reactivation of Aerobic Granules. 99: 83048309.

[3] Liu, X. W., Sheng, G. P. and Yu, H. Q. 2009. Physicochemical Characteristics of Microbial Granules. Biotechnology Advances. 27(6): 1061-70.

[4] Vázquez-Padín, J.R., Mosquera-Corral, A., Campos, J. L. Méndez, R., Carrera, J. and Pérez, J. 2010. Modelling Aerobic Granular SBR at Variable COD/N Ratios Including Accurate Description of Total Solids Concentration. Biochemical Engineering Journal. 49(2): 173-184.

[5] Corsino, S. F., di Biase, A., Devlin, T. R., Munz, G., Torregrossa, M., and Oleszkiewicz, J. A. 2016. Effect of Extended Famine Conditions on Aerobic Granular Sludge Stability in the Treatment of Brewery Wastewater. Bioresource Technology. 226: 150-157.

[6] Ab Halim, M. H., Nor Anuar, A., Abdul Jamal, N. S., Azmi, S. I., Ujang, Z. and Bob, M. M. 2016. Influence of High Temperature on the Performance of Aerobic Granular Sludge in Biological Treatment of Wastewater. Journal of Environmental Management. 184: 271-280.

[7] Manavi, N., Kazemi, A. S. and Bonakdarpour, B. 2017. The Development of Aerobic Granules from Conventional Activated Sludge Under Anaerobic-aerobic Cycles and Their Adaptation for Treatment of Dyeing Wastewater. Chemical Engineering Journal. 312: 375-384.

[8] McSwain, B. S., Irvine, R. L. and Wilderer, P. A. 2004. The influence of Settling Time on the Formation of Aerobic Granules. Water Science and Technology: A Journal of the International Association on Water Pollution Research. 50(10): 195-202

[9] Chen, Y., Jiang, W., Liang, D. T., and Tay, J. H. 2008. Aerobic Granulation Under the Combined Hydraulic and Loading Selection Pressures. Bioresource Technology. 99(16): 7444-7449.

[10] Chen, Y., Jiang, W., Liang, D. T., and Tay, J. H. 2007. Structure and Stability of Aerobic Granules Cultivated Under Different Shear Force in Sequencing Batch Reactors. Applied Microbiology and Biotechnology. 76(5): 1199-208.

[11] Ren, T., Liu, L., Sheng, G., Liu, X., Yu, H., Zhang, M. and Zhu, J. 2008. Calcium Spatial Distribution in Aerobic Granules and Its Effects on Granule Structure, Strength and Bioactivity. 42: 3343-3352.

[12] Henriet, O., Meunier, C., Henry, P. and Mahillon, J. 2016. Improving Phosphorus Removal in Aerobic Granular Sludge Processes Through Selective Microbial Management. Bioresource Technology. 211 : 298-306

[13] Devlin, T. R., di Biase, A., Kowalski, M. and Oleszkiewicz, J. A. 2016. Granulation of Activated Sludge Under Low Hydrodynamic Shear and Different Wastewater Characteristics. Bioresource Technology. 224: 1-7.

[14] Tay, J.H., Liu, Q.S. and Liu, Y. 2001. The Effects of Shear Force on the Formation, Structure and Metabolism of Aerobic Granules. Applied Microbiology and Biotechnology. 57(1-2): 227-233.

[15] Dulekgurgen, E., Artan, N., Orhon, D. and Wilderer, P. A. 2008. How Does Shear Affect Aggregation in Granular Sludge Sequencing Batch Reactors? Relations between Shear, Hydrophobicity, and Extracellular Polymeric Substances. Water Science and Technology: A Journal of the International Association on Water Pollution Research. 58(2): 267-76.

[16] Smolders, G. J., Klop, J. M., Van Loosdrecht, M. C. and Heijnen, J. J. 1995. A Metabolic Model of the Biological Phosphorus Removal Process: I. Effect of the Sludge Retention Time. Biotechnology and Bioengineering. 48(3): 222-33.

[17] De Kreuk, M.K., Pronk, M. and Van Loosdrecht, M.C. M. 2005. Formation of Aerobic Granules and Conversion Processes in an Aerobic Granular Sludge Reactor At Moderate and Low Temperatures. Water Research. 39(18): 4476-84. 
[18] Zheng, Y. M., Yu, H. Q., Liu, S. J. and Liu, X.-Z. 2006. Formation and Instability of Aerobic Granules Under High Organic Loading Conditions. Chemosphere. 63(10): 1791800.

[19] Ghangrekar, M. M., Asolekar, S. R. and Joshi, S. G. 2005. Characteristics of Sludge Developed Under Different Loading Conditions during UASB Reactor Start-up and Granulation. Water Research. 39(6): 1123-1133.

[20] Tay, J. H., Ivanov, V., Pan, S., and Tay, S. L. 2002. Specific Layers in Aerobically Grown Microbial Granules. Letters in Applied Microbiology. 34(4): 254-7.

[21] Muda, K., Aris, A., Salim, M. R., Ibrahim, Z., Yahya, A., Van Loosdrecht, M. C. M. and Nawahwi, M. Z. 2010. Development of Granular Sludge for Textile Wastewater Treatment. Water Research. 44(15): 4341-50.

[22] Adav, S. S., Lee, D. J. and Lai, J. Y. 2007. Effects of Aeration Intensity on Formation of Phenol-fed Aerobic Granules and Extracellular Polymeric Substances. Applied Microbiology and Biotechnology. 77(1): 175-82.

[23] Ghangrekar, M. M., Asolekar, S. R., Ranganathan, K. R., Joshi, S. G. 1996. Experience with UASB Reactor Start-up under Different Operating Conditions. Water Sci. Technol. 34(5-6): 421-428.

[24] Liu, Y., XU, H. L., Yang, S.F. and Tay, J. H. 2003. Mechanisms and Models for Anaerobic Granulation in Upflow Anaerobic Sludge Blanket Reactor. Water Research. 37(3): $661-73$

[25] Beun, J. J., Hendriks, A., Van Loosdrecht, M. C. M., Morgenroth, E., Wilderer, P. A. and Heijnen, J. J. 1999. Aerobic Granulation in a Sequencing Batch Reactor. Water Research. 33(10): 2283-2290.

[26] Liu, Q. S., Liu, Y., Tay, J. H. and Show, K. Y. 2005. Responses of Sludge Flocs to Shear Strength. Process Biochemistry. 40(10): 3213-3217. 